This item was submitted to Loughborough's Research Repository by the author.

Items in Figshare are protected by copyright, with all rights reserved, unless otherwise indicated.

\title{
Retailer service acceptance: simply adding a service to the offer portfolio or committing to marketing it
}

PLEASE CITE THE PUBLISHED VERSION

https://doi.org/10.1080/09593969.2018.1555542

\section{PUBLISHER}

(C) Taylor \& Francis (Routledge)

\section{VERSION}

AM (Accepted Manuscript)

\section{PUBLISHER STATEMENT}

This is an Accepted Manuscript of an article published by Taylor \& Francis in International Review of Retail, Distribution and Consumer Research on 13 Feb 2019, available online:

https://doi.org/10.1080/09593969.2018.1555542

\section{LICENCE}

CC BY-NC-ND 4.0

\section{REPOSITORY RECORD}

Vaittinen, Eija, Sanna Nenonen, and Victoria Story. 2019. "Retailer Service Acceptance: Simply Adding a Service to the Offer Portfolio or Committing to Marketing It". figshare. https://hdl.handle.net/2134/37867. 


\title{
Retailer service acceptance: Simply adding a service to the offer portfolio or committing to marketing it
}

Eija Vaittinen, Sanna Nenonen \& Vicky M. Story

This is a pre-print (non-publisher's document). Please cite the published article:

Eija Vaittinen, Sanna Nenonen \& Vicky M. Story (2019) Retailer service acceptance: simply adding a service to the offer portfolio or committing to marketing it, The International Review of Retail, Distribution and Consumer Research, 29:2, 139-159, DOI:

\begin{abstract}
By virtue of their significant influence on customers' decisions, retailers' acceptance of a service plays a significant role in the success of that service. Therefore, retailers' acceptance of the service and commitment to selling the service must be ensured. However, this issue has attracted limited attention in acceptance research, which tends to focus on goods, technologies and consumers. Based on a survey of consumer durables retailers in three countries, this study focuses on retailer acceptance of a complimentary use-guarantee service, which is meant to maintain customer's ability to use a semi-durable consumer product. The results of this study link retailers' perceived usefulness, and commitment \& effort to their service acceptance. Manufacturer support was found to moderate the relationship between ease of use and acceptance. Further, nationality, retailer's own use of the service as a consumer and the importance of the manufacturer's business for retailers were important for retailer acceptance. Thus, manufacturers need to focus as strongly on retailer acceptance as on the end customer acceptance to ensure service success. They also need to ensure the usefulness of the service for retailer, give retailers a reason to commit to the service
\end{abstract}


sales and provide enough support to make retailers comfortable in selling the service.

Keywords: Service adoption, servitization, supply chain, manufacturing, salesforce

\section{Introduction}

Many manufacturers distribute their offerings through a retailer network, especially in consumer markets. Successful introduction of a service therefore depends on convincing retailers — who are responsible for promoting the service — of its attractiveness (Lenfle and Midler, 2009). As retailers become increasingly powerful (Hultink et al., 1999) with the ability to critically influence customer decisions (Badrinaryanan and Laverie, 2013; Nordfält, 2017), their acceptance of new services is essential in gaining retailers' commitment to market the offering (Hultink and Atuahene-Gima, 2000), in turn increasing customer acceptance (di Benedetto, 1999). However, retailer acceptance is not a given, as the retailer may prefer to focus on existing offerings (Wieske and Homburg, 2008). It follows that sales force adoption of an innovation requires managerial effort; in general, salespeople should be seen as the first customers to whom the innovation needs to be sold (Atuahene-Gima, 1997).

Acceptance is known to be affected by several factors, such as benefits and ease of use (e.g., Chen et al., 2007; Davis, 1986; Smith et al., 2014). However, the current literature on innovation acceptance emphasizes goods, and it remains unclear whether those findings can be generalized to the service domain (Lenfle and Midler, 2009). This is despite the fact that traditional technology acceptance models have more generally been noted as useful for studying services acceptance (Rexfelt and af Ornäs, 2009; Vaittinen et al., 2018). Additionally, the prevailing focus on 
customers' adoption of innovation neglects the role of those who sell and market the service (Athuane-Gima, 1997; De Kerviler et al., 2016; Wieske and Homburg, 2008). The few studies of innovation acceptance among retailers relate to new goods and technologies (e.g., Lin and Chang, 2012; Kaufman et al., 2006), with little research on service acceptance. The lack of focus on understanding the antecedents of acceptance for services is surprising, given the importance of services to most economies. It is also at odds with the growing importance of services for traditionally goods-focused businesses (Witell and Löfgren, 2013), who are seeking competitive advantage through servitization - that is, "the process of creating value by adding services to products" (Baines et al., 2009).

There is some evidence that manufacturers can enhance retailer acceptance of goods, for example, by investing in the supplier-retailer relationship, providing monetary and managerial incentives, and communicating the benefits of the product (Lin and Chang, 2012). However, studies of retailers' and salespersons' adoption processes have, to date, focused mainly on the initial adoption decision (Collins-Dodd and Louviere, 1999; Kaufman et al., 2006; Lin and Chang, 2012)_for example, whether a retailer includes a new product in their selection (Kaufman et al., 2006)while ignoring the later stages of the adoption process. This seems odd, as many studies have highlighted salespersons' potential to influence customer decisions (Athuane-Gima, 1997; Badrinaryanan and Laverie, 2013; di Benedetto, 1999; Hultink and Atuahene-Gima, 2000). Furthermore, the mere introduction of an innovation into the offering does not guarantee either its continued inclusion in the offering (Hultink et al., 1999) or the retailer's willingness to persuade customers to buy the service. This is better described by the retailer's willingness to actively market the service to their customers following the initial adoption decision. In this paper, this 
phase of the adoption process, the active willingness to market the service, is referred to as acceptance. Kaufman et al. (2006) realized the importance of acceptance and called for research to look beyond retailers' initial selection of a new offering to how well it is presented to customers as part of the retailer's offering during the sales process.

Clearly, then, although acceptance research in general has a long history, there is an evident research gap in relation to the acceptance of goods-related consumer services. To address this gap, the present study seeks to identify the antecedents of service acceptance among retailers of consumer semi-durables and to adapt current acceptance models to this context in order to increase understanding of this issue and to offer practical support for the management of retailer service acceptance. The study focuses on a complimentary use-guarantee service, which is meant to maintain customer's ability to use a semi-durable consumer product. Thus, the service is triggered if the product breaks in normal use, and includes retrieval and replacement of the product. This use-guarantee service is offered to consumers by the manufacturer of the product, but marketed and implemented through a retailer network. At the time of the study, the service was something of an innovation in this industrial sector. An example, in a more traditional context, would be a service guarantee, given with the sale of a computer, which would promise that if you unintentionally break your computer the retailer would organize a service employee to collect the broken computer from you, replace the broken part as soon as possible, and bring it back to you ready to use.

The paper contributes to the current literature in three ways. First, it explores retailers, who have previously been studied less than consumers or even than internal salespeople. Second, it focuses 
on goods-related services rather than on technologies and technology-intensive services, which have predominated in previous studies of acceptance. Third, the focus here is on the phase following initial adoption, which is not just about agreeing to offer the service alongside the product offering, but actually making an effort to market it. While earlier studies have tended to focus on the initial adoption decision, many authors have highlighted the importance of this subsequent phase (Lin and Chang, 2012; Kaufman et al., 2006). By taking acceptance research into a new and highly topical context, the present study contributes to the research on acceptance and provides insights for servitization research from a retailer perspective.

\section{Theoretical Background}

\section{The service context and defining service acceptance}

Services are not a homogenous group but can vary widely (Edvardsson et al., 2005). Services have been classified into professional services, service shops, and mass services depending on their characteristics (Silvestro et al., 1992). On the other hand, services have also been classified based on their focus on product or process, or the amount of customer contact they have and the value added in the front office (Shafti et al., 2007). The majority of studies on service adoption and acceptance have focused on technology-intensive services that require active involvement with the technology (e.g. Chen et al., 2007; Jang and Noh, 2011; Lin and Chang, 2011). In contrast to this, the service under study here is goods-focused and the value added by the front office is low, as is the amount of customer contact. It is a goods-based service offered by a manufacturer to consumers who use their semi-durable goods; more precisely, it is a complementary use-guarantee that could be described as a form of warranty.

As a form of guarantee, warranties have an important role in consumer transactions (Murthy and 
Djamaludin, 2002). They have been used, for example, to protect customers buying a good, to signal high goods quality or reliability, and as a value add element in marketing strategy (Murthy and Djamaludin, 2002). From the point of view of consumer behavior, warranty literature mainly sees warranties as something that positively affects consumer product choices through signaling reliability (Murthy and Djamaludin, 2002). However, other research suggests that warranties are not necessarily used to signal goods quality or that with a good reputation, or oppositely with negative information, warranties can become less effective (Chu and Chintagunta, 2011; Grunwald and Hemplmann, 2010; Yeh; 2016). Similarly, popular press is littered with examples of firms being criticized for failing to honor warranties, offering misleading warranties, or providing 'exclusions' that limit the value of such warranties (Knowles, 2017; McCarthy, 2018; Read, 2014). Even within the warranties literature, retailer acceptance of manufacturer warranties has not been the focus of past studies.

In the vast literature on innovation adoption and acceptance, the use of these terms remains fuzzy. In many contexts, adoption and acceptance are used interchangeably (see Planing, 2014), but specific definitions have also been proposed. For example, in the often-cited work by Rogers (1983, p. 21), adoption is defined as a "decision to make full use of an innovation as the best course of action available". In a retail context, Atuahene-Gima (1997) defined adoption in terms of the retailer's commitment and effort. Planing (2014) suggested that while adoption describes the decision to use an innovation, acceptance refers to continued use of the innovation. Following Planing's distinction, the present study focuses on acceptance of a service that retailers have promoted for some time rather than on initial adoption. Therefore, the term acceptance includes retailers' continued promotion and implementation of the service. 
Given the scarcity of studies on retailer acceptance, this study also draws on studies of salespeople's acceptance of goods and technologies, as retailers and company's internal sales people play what is, in many regards, a very similar role when marketing a service. For example, as both intend to sell the service forward, they need to understand the benefits of the service for both the customer and for their own company, and they need to have sufficient information to market the service. In this sense, retailers can be seen as the company's frontline salespeople.

\section{Service acceptance among retailers}

Many manufacturers distribute their goods and service offerings through a retailer network. In such cases, manufacturers' success depends on retailers' acceptance (Kaufman et al., 2006) because retailers influence how customers perceive new offerings (Ahearne et al., 2010). Salesforce literature also identifies that the acceptance of new offerings affects sales performance because, without it, marketing efforts may be dysfunctional (Athuane-Gima, 1997). Indeed, it has been suggested that service innovations can be successful only when frontline employees adopt the service and promote it to their customers (Cadwallader et al., 2010).

Retailer or salesforce acceptance of new offerings is, therefore, essential, but this is not a given or without challenges. For example, in their study of travel service brand extensions, Wieske and Homburg (2008) reported that the salesforce might prefer to focus on existing goods and services because of uncertainty about the success of a new offering. If they doubt customers' interest in the product, salespeople may hesitate to market it because of a fear of negative consequences for their customer relationships (Wieske and Homburg, 2008). Investigating salesforce success 
expectations and sales efforts during a new industrial product launch, Beuk et al. (2014) emphasized that salespeople need to overcome uncertainties, as low expectations of success lead to reduced sales effort, resulting in low customer acceptance of the offering.

To summarize, retailers are significant stakeholders who can affect customer acceptance and ultimately the success of new offerings. However, it cannot be assumed that those responsible for selling the offering are willing to accept and promote it. Given their essential role and related challenges, it is important to understand what influences the acceptance of those selling the service (Janssens, 2015), in this case, the retailer staff. However, previous studies have not addressed retailer acceptance in the case of extensions from goods to services but have instead focused on new goods. Extensions of this kind are arguably more complex for retailers than broadening the offering with other goods from the same manufacturer, and, thus, offer an important context in which to study acceptance.

\section{Antecedents of retailer service acceptance}

This research builds on studies of technology-intensive services, which is the most extensively studied domain closest to the goods-related services that are typical of the servitizing manufacturers, as the one studied here. The present work is based on Davis' (1986) technology acceptance model, which has been widely utilized in several fields and found to be a suitable framework for investigating technology-intensive services (Chen et al., 2007; Kallweit et al., 2014; Smith et al., 2014). In fact, among commonly used models, such as the innovation diffusion model, the theory of reasoned action and the theory of planned behavior, this is the most widely accepted model of acceptance (Lin and Chang, 2011). However, TAM has been criticized for addressing only two main independent variables (Kallweit et al., 2014), and in the retail context, other relevant 
independent variables must be identified. The following sections discuss the antecedents relevant to retailer acceptance of goods-related services.

\section{Perceived ease of use}

Retailer perceptions of the service to be sold or marketed are likely to be affected by the number and difficulty of the extra tasks service requires. This issue can be understood in terms of the TAM variable perceived ease of use. This is similar to Rogers (1983) concept of complexity (Moore and Benbasat, 1991), referring to how difficult the innovation is to use and understand. The importance of ease of use has been noted for consumer acceptance of several services, such as self-service information technologies in purchasing (Kallweit et al., 2014), as well as attitudes to RFID applications and intention to use them (Smith et al., 2014). In relation to salesforce acceptance, Lenfle and Midler (2009) described how a service's operational complexity may cause hesitancy among salespeople. Additionally, Mallat and Tuunaninen (2005) found that complexity hindered retailer willingness to adopt mobile payment services. Clearly, then, a service's perceived ease of use is likely to be an antecedent of retailer service acceptance. Thus, we hypothesize that:

H1. Perceived ease of use of the service has a positive relationship with retailer's service acceptance.

\section{Perceived usefulness}

A service's usefulness seems important for the retailer for two reasons. First, it is unlikely that retailers' customers would want a service that is not of use to them, or that a retailer would want to sell it. Second, if a service is perceived to be of use to retailers, it seems likely that this perception 
will increase their willingness to accept it. The TAM factor perceived usefulness (Davis, 1986) overlaps with another commonly used antecedent, relative advantage, referring to the degree to which an innovation improves on previous solutions - for example, in terms of economics or status (Rogers, 1983). Perceived usefulness has also been identified as a significant antecedent in several contexts (Jang and Noh, 2011; Moore and Benbasat, 1991). In the retail domain, Lin and Chang (2012) found that product benefits contribute to cellular phone retailers' acceptance of a new product. Mallat and Tuunainen (2005) identified the differing benefits of mobile payment systems for retailers and their customers (such as enhanced image and customer service) as relevant drivers of retailer use. This supports the view that retailer acceptance of a service relates to its benefits for the retailer and thus, we hypothesize:

H2. Perceived usefulness has a positive relationship with retailer's service acceptance.

\section{Retailer commitment and effort}

Salespeople may dislike the extra effort or changes in their selling routines required by marketing new products (Andersson and Robertson, 1995), and this may encourage them to continue to promote existing offerings (Beuk et al., 2014). However, because salespeople need to distribute their sales efforts across different offerings, they may assume that a beneficial new product will promote itself, requiring only minimal effort from them (Ahearne et al., 2010). Overall, they must balance their sales efforts, and investing effort in a new offering will reduce the effort allocated to other offerings (Beuk et al., 2014). However, Athuane-Gima (1997) has noted that successful marketing depends on more than mere effort and must be combined with commitment; it has even been claimed that effort and commitment are the constituent elements of salesforce adoption 
(Athuane-Gima, 1997; Hultink and Athuane-Gima, 2000). On that basis, commitment and effort are hypothesized to have a positive effect on retailer service acceptance.

H3. Commitment and effort have a positive relationship with retailer's service acceptance.

\section{Result demonstrability}

Result demonstrability refers to the tangibility of outcomes when using an innovation. This is derived from Rogers' (1983) observability antecedent in light of the complexity of the original construct (Moore and Benbasat, 1991). Kapoor et al. (2015) identified result demonstrability as a significant factor in the adoption of an interbank mobile payment service; it has also proved important in other contexts, such as investment decision making in the food industry (Heyder et al., 2012). It is logical to think that the importance of this factor will increase in the case of retailer service acceptance. For example, the retailer's marketing success depends on how well they can describe the service's benefits for the customer, and given that services can be more difficult to understand than goods, because of their intangible nature (Johne and Storey, 1998), it would seem logical that higher levels of demonstrability are likely to make acceptance of the service more likely. Thus, we hypothesize:

H4. Perceived result demonstrability has a positive relationship with retailer's service acceptance.

\section{Manufacturer support}

Retailer-manufacturer relationships have attracted some research interest. For example, Lin and Chang (2012) and Kaufman et al. (2006) found that this relationship was important for retailers' 
new product adoption decisions and Bronnenberg et al. (2002) found the same effect for new brand adoption. Badrinarayanan and Laverie (2013) discovered that trust in a manufacturer and their salespeople had a positive effect on retail associates' actions in recommending that manufacturer's brand to their customers. Pellegrini and Zanderighi (1991) found that existing suppliers have a higher probability of getting their new products accepted than suppliers without existing relationships with a retailer. Further, they noted that retailers perceive that products by new suppliers have lower consumer value and that their marketing skills are inferior to those of established suppliers (Pellegrini and Zanderighi, 1991). Manufacturer reliability has been noted to improve the likelihood that they will be accepted and similarly, the support manufacturers offer in the form of marketing efforts makes them more desirable business partners in retailer's eyes (Hansen and Skytte, 1998). Kaufman et al. (2006) highlighted the importance of the relationship with a manufacturer for retailer product acceptance, especially when the product is moderately attractive. The relationship between retailer and manufacturer and the support the manufacturer provides would, therefore, be expected to moderate retailer service acceptance. According to Kaufman et al. (2006), a product's attractiveness or lack of attractiveness is enough to direct retailer decision-making, but a good relationship with the supplier can sway the retailer to adopt a moderately attractive product (Kaufman et al., 2006). Therefore, the expectation is that manufacturer support will have a positive effect on the relationship between the independent variables and retailer's service acceptance.

H5a. The relationship between retailer's perceived ease of use and service acceptance will be stronger (more positive) when manufacturer support is greater.

H5b. The relationship between retailer's perceived usefulness and service acceptance will be 
stronger (more positive) when manufacturer support is greater.

H5c. The relationship between retailer's perceived result demonstrability and service acceptance will be stronger (more positive) when manufacturer support is greater.

H5d. The relationship between retailer's commitment and effort and service acceptance will be stronger (more positive) when manufacturer support is greater.

Based on these potential antecedents, Figure 1 captures the proposed research model of retailer service acceptance.

FIGURE 1 HERE

\section{Methodology}

\section{Data collection}

The data were collected by means of a questionnaire distributed to retailers of a use-guarantee service for end customers. The service was introduced by a large manufacturing company whose semi-durable goods target consumers and professional users. The company has a long history as a manufacturer of high quality goods, but a few years ago, it began to look for new service opportunities as a means of getting closer to end customers, since they do not gain data about their customers through retailers.

The manufacturer's retailers sell their goods alongside similar goods from other manufacturers. Some retailers are more active in selling this manufacturer's goods (e.g. due to higher margins), whereas others may favor other manufacturer's goods, (e.g. due to lower prices). After all, it is up to the retailers to choose which brands they present and where they wish to focus their marketing 
effort, as the manufacturers are not in a position to demand sales; they can merely encourage and offer incentives. The manufacturer keeps its retailers informed about their products through visits and marketing materials.

The service in question is a complimentary use-guarantee service that enables customers to continue using the semi-durable consumer good if it breaks during normal use. It is available to consumers who register when purchasing a certain type of good from the case company retailers. The use-guarantee service is provided by the manufacturer for end customers but marketed and implemented by retailers. The retailers studied had marketed the service since its launch, a few years ago, and, thus, represent a suitable population for the study of service acceptance (i.e., by virtue of their ongoing marketing of the service).

The questionnaire was distributed to all the retailers of this manufacturer, based on the manufacturer's records, as an e-survey in three European countries in which the service was offered, all in the same geographic region. The questionnaire was made available for three weeks, during which time two reminder messages were sent to non-respondents. A total of 1008 responses were received, yielding a response rate of $14.1 \%$. However, 47 of the respondents did not belong to the target group, reducing the number of respondents to 961 . Respondents were from retailers of two types: those whose main business was retailing the semi-durable goods in question and those whose main business related to other goods. For the purposes of this study, we concentrated on the first group, who were more focused on the service investigated here. This yielded a final sample of 403 respondents, whose background information is summarized in Table 1. 


\section{TABLE 1 HERE}

\section{Measures}

As this was a new research context, our questionnaire modified Hultink and Atuahene-Gima's (2000) salesforce product adoption survey and earlier work on innovation adoption by Moore and Benbasat (1991). Additionally, a study of retailer new product acceptance by Lin and Chang (2012) was used to capture retailer support, and Chen et al.'s (2000) study of electronic toll collection was referred to for ease of use items. In addition to the questions adapted from these surveys to fit the service adoption context, one case-specific question was constructed in collaboration with the case company, as described in the measures section. The questionnaire was finalized on the basis of feedback provided by other academics.

Independent variables and moderator. The questionnaire included 15 items related to acceptance of a complimentary goods-related service in the retail context, referring to such themes as retailers' service marketing effort, service usefulness, ease of use, result demonstrability and cooperation and communication with the manufacturer (Table 3). Of these, 14 items were modified from previous questionnaires to fit the retail and service contexts, and the remaining item (handling service implementation claims goes smoothly with the manufacturer) was created for this context to capture manufacturer support. In addition, there were questions about respondents' background, their own use of the service and the stores they represented.

Dependent variable. The dependent variable described retailers' acceptance of the service. A traditional measure would be data recorded about an individual salesperson's performance on 
objectives such as percentage of sales quota for a service (see for example Ahearne et al., 2010). In the present case, salesperson-specific marketing data for the service were not recorded by the retailers nor by the manufacturer, and, for example, observations of an individual retailer's marketing performance were not possible due to the large size of the target group. Instead, each individual retailer's acceptance was assessed by means of a self-report question, ranging from telling none of their customers about the service to marketing it to all customers (Table 2). The dependent and independent variables were measured on different scales to avoid common method bias (Podsakoff et al., 2003).

Control variables. To reduce the risk of omitted-variable bias, we chose six control variables related to the respondents and the company they represented. The first respondent-related control variable was age, given the existing evidence that age is important for adoption (Ching and Ellis, 2004). Following Wieske and Homburg (2007), we also included gender to control its effect on respondents' perceptions of the service. In addition, we included respondents' nationality in the analysis, as country-specific factors might affect respondents' adoption choices (Gupta and Arora, 2017). As earlier research has shown that previous experiences can affect acceptance decisions (Park and Joon, 2013), we chose respondents' registration as a service user as the fourth control variable to distinguish the possible effect of personal use of the service (as the service is a consumer service the retailers can also have the service in personal use).

The first company-related control variable was percentage of revenues from manufacturer's goods (a categorical variable entailing five classes). This was included because retailers who are more dependent on the manufacturer may have a more positive (Bronnenberg et al., 2002) or negative 
(van Everdingen et al., 2011) view of the service than other retailers. Following Bronnenberg et al. (2002), we also included number of company employees in the analysis, as firm size has been found to affect adoption in many contexts. Table 2 presents the classification of control variables.

\section{TABLE 2 HERE}

\section{Data Analysis And Results}

\section{Factor analysis}

We conducted exploratory factor analysis (EFA) separately for each expected factor. EFAs were implemented using principal axis factoring, promax rotation and pairwise deletion (Hair et al., 2010). Bartlett's test of sphericity was significant for all EFAs $(\mathrm{p}<0.001)$, and the Kaiser-MeyerOlkin measure of sampling adequacy was greater than 0.6 for all factors other than manufacturer support $(\mathrm{KMO}=0.5)$

Common method variance was tested using Harman's one-factor method (Podsakoff et al., 2003). The single-factor model explained $43.2 \%$ of the total variance; as less than half, this indicates that common method variance is not of great concern but cannot be completely excluded (Podsakoff et al., 2003).

The items loaded well enough on their respective constructs, as most of the loadings were above 0.6, and only one loading was below 0.5 (loading $=0.473)($ Costello and Osborne, 2011). In addition, the factor constructs indicated good internal consistency, with Cronbach alpha values ranging between 0.77 and 0.85 (Hair et al., 2010). Factors were created by taking the average of items for each factor; more detailed information is presented in Table 3. 
TABLE 3 HERE

\section{Regression analysis}

The relationship between the different factors and retailers' acceptance of the service was examined using ordinal logistic regression analysis with a logit link function, as the dependent variable is ordinal (see Table 2). The Appendix presents descriptive statistics and Spearman's correlations between the variables utilized in the regression. To check the results for multicollinearity, variance inflation factors (VIFs) were calculated using linear regression. As all VIFs were below 5 (i.e., below the commonly used cutoff value), multicollinearity should not be a problem (Hair et al., 2010; Jung and Seock, 2017).

In the first model, only control variables were included to create a baseline model to have a comparison point. The four factors formed in EFA were added to the second model. For the third model, we further added the interactions of manufacturer support during service implementation. The factors were mean centered before the analysis, as instructed by Dawson (2014). The increase in the Nagelkerke Pseudo $\mathrm{R}^{2}$ from the first to the second model and to the final model $(0.223->$ $0.366->0.377)$ and the decrease in -2 Log Likelihood (936.6 -> $718.6->714.0)$ indicate that the final model offered the best explanation of the data. Furthermore, the test of parallel lines was not statistically significant $\left(\chi^{2}=50.8 ; p=0.364\right)$ for the final model, indicating that the proportional odds assumption was not violated (National Centre for Research Methods, 2011).

Because there were some continuous independent variables, analysis had a high number of value combinations of dependent and independent variables that are not present, which can skew the 
Pearson's and Deviance goodness-of-fit statistics. Therefore, these should not be given weight and are not reported here. Instead, emphasis is placed on measures of association such as pseudo $\mathrm{R}^{2}$ (National Centre for Research Methods, 2011). The ordinal regression results are presented in Table 4.

\section{TABLE 4 HERE}

Two antecedents of service acceptance (retailer's perceived usefulness and commitment $\&$ effort) were statistically significantly related to retailers' service acceptance $(B=0.453, p<0.05$ and $B$ $=0.782, \mathrm{p}<0.01$, respectively). Respondents who felt that the service had benefits for them and were committed to investing effort in promoting the service more frequently to their customers were more likely to have accepted the service than other retailers. Interestingly, manufacturer support seems to only significantly moderate retailers' perceptions of ease of use $(B=-0.304 ; p<$ 0.05). Due to lack of tools that exists, for example, for linear, Poisson and logistic regressions (Dawson, 2014) a plot of the interaction could not be made. However, the following information and figure 2 demonstrate the relationship seen in the data. Ease of use seems more important when the retailer perceives manufacturer support to be high, as the difference in acceptance is greater for respondents with high manufacturer support with different levels of ease of use. However, the relation may be even stronger, as very few respondents perceived ease of use as high and manufacturer support as low. For that reason, values smaller than two (on a scale of 1-5) were included in the high category and values larger than 3.5 in the low category. As a result, the category high ease of use-high manufacturer support includes as many as 175 people. However, the lack of people in the high ease of use-low manufacturer support category can illustrate the 
strong relationship between these two variables, which is also apparent in their high correlation (Spearman correlation $0.565, \mathrm{p}<0.001$ ).

\section{FIGURE 2 HERE}

In addition, retailers who themselves had a service registration accepted the service significantly more often than those without a service registration $(B=0.739 ; p<0.01)$. Of the other control variables, nationality and percentage of revenue from the manufacturer's goods were significantly related to retailer service acceptance $(B=-1.293, p<0.001$ and $B=-1.251, p<0.001$ for nationality, and $\mathrm{B}=-0.193, \mathrm{p}<0.05$ for revenue percentage). When compared to country $\mathrm{C}$, respondents from countries A and B exhibited higher levels of acceptance, as did respondents who attributed a larger percentage of their revenue to selling the manufacturer's goods. The variables and their relation to marketing performance are illustrated in Figure 3.

\section{FIGURE 3 HERE}

\section{Discussion}

\section{Antecedents of service acceptance in a retailer context}

This study contributes to the wider adoption and acceptance literature by providing an initial insight into the antecedents of retailer acceptance of goods-related services targeted at their customers. While the structure of this model of retailer service acceptance seems to align with previous findings in other domains (product, technologies and technology-intensive services) and customer contexts, there are some nuanced differences and unique aspects. In the present context, the focus shifts from customer benefits and convenience when using the service to benefits and convenience for the retailer. This reflects Athuame-Gima's (1997) view that retailers are the first 
customers to whom the service needs to be sold, making end customers' experiences secondary. On that basis, distinct models are needed for retailer and customer acceptance.

The present study revealed that the benefits (i.e., perceived usefulness) for retailers offering the service and the commitment and effort needed are important for retailer service acceptance. In offering the service, retailers are seeking to gain something, even where the service does not yield direct monetary results in terms of commission. This is significant, as it implies that retailers perceive advantages in offering manufacturer's services beyond direct monetary rewards; for example, they may see a service as a means of selling more goods or goods with higher margins. However, one could assume that the importance of benefits would increase when a retailer can achieve benefits in the form of direct returns from the new services. Especially since earlier research has found that retailers pay attention to an innovation's ability to add to their bottom-line (Plouffe et al., 2001).

The present findings confirm that salespersons' commitment \& effort are important for acceptance, as suggested by the earlier literature on retailer acceptance of goods (see Hultink and AtuaheneGima, 2000). On the other hand, against expectations, no statistically significant relationship was found between result demonstrability and retailer service acceptance. One possible explanation is that result demonstrability may be mediated by commitment $\&$ effort. This is plausible, as an understanding of the service and the ability to demonstrate its results are required if one is to invest effort in marketing the service and actually committing to it. Additionally, the high correlation between these two aspects (Spearman correlation 0.516, $p<0.001$ ) may indicate such a relationship. 
Retailer's perceived ease of use was found to have no independent effect on retailer service acceptance. This aligns with some earlier studies in a consumer context, suggesting that the effect of ease of use decreases in moving from an initial adoption decision to acceptance of the service (e.g., Jang and Noh, 2011). However, the interaction effect of ease of use and manufacturer support was found to affect retailer adoption. It seems that retailers who perceived manufacturer support as low generally exhibited lower service acceptance than those who perceived manufacturer support as high. However, the difference in acceptance level between those who perceived the service's ease-of-use to be high and those who perceived it as low is smaller among retailers who perceived manufacturer support as low than among those who perceived manufacturer support as high. This may not reveal the whole effect, as almost no retailers exhibited high perceived manufacturer support and low perceived ease of use. This may suggest that good manufacturer support can effectively reduce the effect of the service implementation challenges faced by retailers. This is also a pioneering study in investigating the role of manufacturer support or relationship as a moderating variable, as most previous studies have focused on its direct effect (e.g., Lin and Chang, 2012).

We also found that some of the control variables were related to retailer service acceptance. Of the respondent-related control variables, retailer service registration and nationality were linked to service acceptance. Service registration may increase a retailer's knowledge of the service, making marketing easier, as retailers can base marketing arguments on their own experiences. Additionally, the literature on services suggests that earlier use of the same or similar services can have a positive impact on future use of services (Johne and Storey, 1998; Park and Kim, 2013; 
Rexfelt and af Ornäs, 2009). Following this logic, it may also be that use of a service can improve one's perception of it, making those retailers more willing to discuss the service with customers. The study also revealed differences in acceptance between respondents from different countries. This is surprising, as all three countries are located in the same geographic region and resemble each other culturally and socially. It is possible that the manufacturer's and/or retailers' marketing practices diverge in the different countries, which might explain differences in marketing performance. This is an important finding, as it highlights the need to consider nationality even when countries seem similar in terms of culture and geography.

One company-related control variable-retailer revenue percentage from selling the manufacturer's goods - was linked to service acceptance. Those retailers earning a higher percentage of their revenue from the manufacturer's goods were found to market the service more frequently to their customers. This seems logical; if selling the manufacturer's goods is important for the retailer's business, the retailer is likely to have a favorable perception of a service that can enhance those sales. However, this result conflicts with van Everdingen et al.'s (2011) finding that higher dependency on a manufacturer reduces a retailer's eagerness to accept new offerings from that manufacturer. This difference may relate to the complimentary and additional nature of the service investigated here, which does not increase retailers' dependency on the manufacturer but makes it easier to market the goods. On the other hand, this may also reflect the manufacturer power over those retailers who are more dependent on them. Thus, although retailers can have significant power in their relationship with the manufacturer, due to their ability to affect consumer choices (Porter, 1974), the manufacturer may be able to more easily convince retailers for whom they are an important provider of goods to also sell their services. 


\section{Managerial implications}

The present findings about retailers' influence on the success of services will be of interest to both manufacturers and retailer organizations. It is especially important to consider the retailer's role in selling or marketing new services, as retailer acceptance affects consumer service acceptance. Therefore, retailers are important for servitizing firms focused on consumers - working with them can be highly beneficial and lead to more successful servitization efforts if manufacturer's can achieve retailer acceptance. This study indicates how manufacturers and retail managers can enhance retailer service acceptance and related marketing performance.

As a first recommendation, we would suggest that servitizing manufacturing companies offering services through retailer channels should emphasize the benefits for retailers to convince them to sell services more actively. Manufacturers should also strive to increase retailers' effort and commitment in relation to services - for example, by making sure that retailers understand the service well and have a sense of its importance. This study also confirms that manufacturers should seek to develop their relationship with retailers and should ensure that retailers get sufficient support when selling services, so mitigating risk that retailers find the service too difficult to implement. These actions are especially important in the context of complex services; as Janssens (2015) noted, complexity undermines retailers' interest in marketing the offering. Additionally, as retailers must split their time between different offerings (Beuk et al., 2014), ease of marketing is a central issue when retailers are deciding whether to direct their efforts to the new offering.

For smooth marketing, we recommend that manufacturers provide marketing material and training 
to convince retailers about the benefits of the service. In addition, clear presentation of its results by the manufacturer can enhance retailer service acceptance. Potentially, even more effective in enhancing retailer service acceptance is to run initiatives to get retailer staff to try out the service, which appears to make marketing the service even more appealing and effortless. Manufacturers also need to ensure that the retailer sees the expected customer demand as positive, as the salesforce may hesitate to market new offerings if they perceive that customers are not interested (Wieske and Homburg, 2008). This may require customer pull efforts as well as retailer push efforts. Further, previous literature has found information sharing and cooperation beneficial for manufacturer and retailer (Kulp et al., 2004). Thus, in addition to providing information about the new service other kinds of data sharing should also be considered, such as, data on customer needs.

As these results also suggest that national characteristics may affect service acceptance, harnessing the best marketing practices can improve overall marketing performance. Managers in companies operating in several countries should exploit any cross-cultural learning to enhance service marketing. For example, managers might usefully compare service marketing and selling practices and outcomes across countries to identify the most effective practices and apply them with due regard to cultural effects.

Another important finding here is that retailers who earn a smaller percentage of revenue from a manufacturer's goods are less likely to market their goods-related services. Manufacturers need to invest in convincing these retailers to market the service, not only in the case of those who mostly sell competitors' goods but also where retailers' main business is selling other kinds of goods, leaving little scope for the goods in question. In such cases, marketing other goods may seem more 
profitable and effortless for the retailer, and the manufacturer should offer specific assurances about the importance and benefits of marketing their service that has only minor effects on the retailer's business.

\section{Limitations and further research}

This study has two clear limitations. First, as all the data were gathered using a single questionnaire, the possibility of common method variance cannot be completely excluded. Future research should, therefore, ensure that part of the information (for example, the dependent variable) is acquired through a different medium. As we used a single questionnaire, we can draw conclusions only about the relation of the variables but not about causality, and further studies should be designed to address causal connections.

Second, the service examined here is a specific complimentary service that is clearly of use to consumers. This makes positive perceptions more likely, causing the data to be skewed. While some factors may, therefore, be typical only for this kind of service, others might be of interest for a non-complimentary service where, for example, cost might be an issue. Complimentary services are a highly interesting area of study, as this is where many manufacturers commence servitization. However, further research should also explore non-complimentary services (Witell and Löfgren, 2013), considering their direct returns. Further, to complement this there is need to consider the costs for the retailer in future studies. Additionally, the model of acceptance of goods-related services presented here is a first step of model specification in this context and requires further validation using confirmatory methods. 
This study opens to wider discussion the question of how retailer service acceptance affects service success. This issue should be further explored in a different context where service implementation is more common. Additionally, there is a need to assess the suitability of these factors to represent service acceptance more generally, beyond the context of complimentary goods-related services. Future studies should also address the relationship between result demonstrability and commitment and effort. In highlighting directions for further research, the present study serves as a good starting point for deeper investigation of retailer service acceptance that have not gained attention in the existing acceptance literature. 


\section{References}

Ahearne, M., Rapp, A., Hughes, D. E., \& Jindal, R. (2010). Managing sales force product perceptions and control systems in the success of new product introductions. Journal of Marketing Research, 47(4), 764-776.

Anderson E., \& Robertson, T. S. (1995). Inducing multiline salespeople to adopt house brands. Journal of Marketing, 59(4), 16-31.

Atuahene-Gima, K. (1997). The adoption of new products by the sales force: The construct, propositions and managerial implications. Journal of Product Innovation Management, 14(6), $498-514$.

Badrinarayanan, V., \& Laverie, D. A. (2013). The Role of Manufacturers' Salespeople in Inducing Brand Advocacy by Retail Sales Associates. Journal of Marketing Theory and Practice, 21(1), $57-70$.

Baines, T.S., Lightfoot, H.W., Benedettini, O., and Kay, J.M. (2009), The servitization of manufacturing: A review of literature and reflection on future challenges. Journal of Manufacturing Technology Management, 20(5), 547-567.

di Benedetto, A. (1999). Identifying the key success factors in new product launch. Journal of Product Innovation Management, 16(6), 530-544.

Beuk, F., Malter, A. J., Spanjol, J., \& Cocco, J. (2014). Financial incentives and salesperson time orientation in new product launch: A longitudinal study. Journal of Product Innovation Management, 31(4), 647-663.

Bronnenberg, B. J., Mahajan, V., \& Mela, C. (2002). Market roll-out and retail adoption for new brands of non-durable goods (No. 372). Working paper. URL: https://faculty.fuqua.duke.edu/ mela/bio/papers/Bronneberg_Mela_2002.pdf 
Cadwallader, S., Jarvis, C. B., Bitner, M. J. \& Ostrom, A. L. (2010). Frontline employee motivation to participate in service innovation implementation. Journal of the Academy of Marketing Science, 38(2), 219-239.

Chen, C. D., Fan, Y. W., \& Farn, C. K. (2007). Predicting electronic toll collection service adoption: An integration of the technology acceptance model and the theory of planned behavior. Transportation Research Part C: Emerging Technologies, 15(5), 300-311.

Ching, H. L., \& Ellis, P. (2004). Marketing in cyberspace: what factors drive e-commerce adoption? Journal of Marketing Management, 20(3-4), 409-429.

Chu, J., \& Chintagunta, P. K. (2011). An empirical test of warranty theories in the US computer server and automobile markets. Journal of Marketing, 75(2), 75-92.

Collins-Dodd, C., \& Louviere, J. J. (1999). Brand equity and retailer acceptance of brand extensions. Journal of Retailing and Consumer Services, 6(1), 1-13.

Costello, A. B., \& Osborne, J. W. (2011). Best practices in exploratory factor analysis: four recommendations for getting the most from your analysis. Practical Assessment, Research and Evaluation 2005; 10. URL http://pareonline. net/getvn. asp, 10(7).

Davis, F. D. (1986). A Technology Acceptance Model for Empirically Testing New End-User Information Systems: Theory and Results. Doctoral dissertation. Cambridge, MA: MIT Sloan School of Management.

Dawson, J. F. (2014). Moderation in management research: What, why, when, and how. Journal of Business and Psychology, 29(1), 1-19.

Edvardsson, B., Gustafsson, A., \& Roos, I. (2005). Service portraits in service research: a critical review. International journal of service industry management, 16(1), 107-121.

van Everdingen, Y. M., Sloot, L. M. , van Nierop, E., \& Verhoef, P. C. (2011). Towards a further 
understanding of the antecedents of retailer new product adoption. Journal of Retailing, 87(4), $579-597$.

Gounaris, S., \& Koritos, C. D. (2012). Adoption of technologically based innovations: The neglected role of bounded rationality. Journal of Product Innovation Management, 29(5), $821-838$.

Grunwald, G., \& Hempelmann, B. (2010). Impacts of reputation for quality on perceptions of company responsibility and product-related dangers in times of product-recall and public complaints crises: Results from an empirical investigation. Corporate Reputation Review, 13(4), 264-283.

Gupta, A., \& Arora, N. (2017). Understanding determinants and barriers of mobile shopping adoption using behavioral reasoning theory. Journal of Retailing and Consumer Services, 36, $1-7$.

Hair J., Black, W., Babin, B., \& Anderson, R. (2010). Multivariate data analysis - a global perspective. New Jersey: Pearson education.

Hansen, T. H., \& Skytte, H. (1998). Retailer buying behaviour: a review. The International Review of Retail, Distribution and Consumer Research, 8(3), 277-301.

Heyder, M., Theuvsen, L., \& Hollmann-Hespos, T. (2012). Investments in tracking and tracing systems in the food industry: a PLS analysis. Food Policy, 37(1), 102-113.

Hultink, E. J., \& Atuahene-Gima, K. (2000). The effect of sales force adoption on new product selling performance. Journal of Product Innovation Management, 17(6), 435-450.

Hultink, E. J., Thölke, J. M., \& Robben, H. S. (1999). Retailers' adoption decision of new consumer durables. Journal of Product Innovation Management, 16(5), 483-490.

Jang, H. Y., \& Noh, M. J. (2011). Customer acceptance of IPTV service quality. International 
Journal of Information Management, 31(6), 582-592.

Janssens, T. T. (2015). Antecedents of sales force new product adoption and the effect of adoption on sales performance. Master innovation management (IMA), 405. Eindhoven: Technische Universiteit Eindhoven.

Johne, A., \& Storey, C. (1998). New service development: a review of the literature and annotated bibliography. European journal of Marketing, 32(3/4), 184-251.

Jung, N. Y., \& Seock, Y. K. (2017). Effect of service recovery on customers' perceived justice, satisfaction, and word-of-mouth intentions on online shopping websites. Journal of Retailing and Consumer Services, 37, 23-30.

Kallweit, K., Spreer, P., \& Toporowski, W. (2014). Why do customers use self-service information technologies in retail? The mediating effect of perceived service quality. Journal of retailing and consumer services, 21(3), 268-276.

Kapoor, K. K., Dwivedi, Y. K., \& Williams, M. D. (2015). Examining the role of three sets of innovation attributes for determining adoption of the interbank mobile payment service. Information Systems Frontiers, 17(5), 1039-1056.

Kaufman, P., Jayachandran, S., \& Rose, R. L. (2006). The role of relational embeddedness in retail buyers' selection of new products. Journal of Marketing Research, 43(4), 580-587.

De Kerviler, G., Demoulin, N. T., \& Zidda, P. (2016). Adoption of in-store mobile payment: Are perceived risk and convenience the only drivers? Journal of Retailing and Consumer Services, $31,334-344$.

Knowles, T. Transparency fears over housebuilder warranties. The Times, 29 August. Accessed 18 September 2018. https://www.thetimes.co.uk/article/transparency-fears-overhousebuilder-warranties-6spvmzcj0 
Kulp, S. C., Lee, H. L., \& Ofek, E. (2004). Manufacturer benefits from information integration with retail customers. Management science, 50(4), 431-444.

Lenfle, S., \& Midler, C. (2009). The launch of innovative product-related services: Lessons from automotive telematics. Research Policy, 38(1), 156-169.

Lin, J. S. C., \& Chang, H. C. (2011). The role of technology readiness in self-service technology acceptance. Managing Service Quality: An International Journal, 21(4), 424-444.

Lin, J. S. C., \& Chang, Y. C. (2012). Retailers' new product acceptance decisions: incorporating the buyer-supplier relationship perspective. Journal of Business \& Industrial Marketing, 27(2), 89-99.

Mallat, N., \& Tuunainen, V. K. (2005). Merchant adoption of mobile payment systems. Paper presented at International Conference on Mobile Business, Sydney. IEEE Computer Society, $347-353$.

McCarthy, K., (2018). 'Our way or the highway' warranty scams shot down by US watchdog: It's OK to use unofficial parts to repair your gear. The register, 10 April. Accessed 18 September 2018.https://www.theregister.co.uk/2018/04/10/ftc_warranty_scam/

Moore, G. C., \& Benbasat, I. (1991). Development of an instrument to measure the perceptions of adopting an information technology innovation. Information Systems Research, 3(2), 192222.

Murthy, D. N. P., \& Djamaludin, I. (2002). New product warranty: A literature review. International Journal of Production Economics, 79(3), 231-260.

National Centre for Research Methods. (2011). Using Statistical Regression Methods in Education Research - $\quad$ Module 5: Ordinal Regression. URL: http://www.restore.ac.uk/srme/www/fac/soc/wie/research- 
new/srme/modules/mod5/index.html

Nordfält, J. (2017). The new retailer - editorial. Journal of Retailing and Consumer Services, 34, 309-310.

Park, E., \& Joon Kim, K. (2013). User acceptance of long-term evolution (LTE) services: an application of extended technology acceptance model. Program, 47(2), 188-205.

Pellegrini, L., \& Zanderighi, L. (1991). New products: manufacturers' versus retailers' decision criteria. International Review of Retail, Distribution and Consumer Research, 1(2), 149-174.

Planing, P. (2014). Innovation acceptance: The case of advanced driver-assistance systems. Wiesbaden: Springer Gabler.

Plouffe, C. R., Hulland, J. S., and Vandenbosch, M. (2001). "Research report: rich-ness versus parsimony in modeling technology adoption decisions - understanding mer-chant adoption of a smart card-based payment system", Information Systems Research, 12(2), 208-222.

Podsakoff, P. M., S. B. MacKenzie, J-Y. Lee, and N. P. Podsakoff. (2003). Common method biases in behavioral research: A critical review of the literature and recommended remedies. Journal of Applied Psychology, 88 (5): 879-903.

Porter, M. E. (1974). Consumer behavior, retailer power and market performance in consumer goods industries. The Review of Economics and Statistics, 419-436.

Read, S. (2014). Co-op challenges rivals by offering no-profit warranties. Independent, 14 October. Accessed 18 September 2018. https://www.independent.co.uk/money/spendsave/co-op-challenges-rivals-by-offering-no-profit-warranties-9792093.html

Rexfelt, O., \& af Ornäs, V. H. (2009). Consumer acceptance of product-service systems: designing for relative advantages and uncertainty reductions. Journal of Manufacturing Technology Management, 20(5), 674-699. 
Rogers, E. (1983). Diffusion of innovations. New York: The Free Press.

Schmidt, M. J., \& Hollensen, S. (2006). Marketing research: An international approach. Harlow: Pearson Education.

Shafti, F., Van Der Meer, R., \& Williams, T. (2007). An empirical approach to service classification for productivity management studies. The Service Industries Journal, 27(6), 709-730.

Silvestro, R., Fitzgerald, L., Johnston, R., \& Voss, C. (1992). Towards a classification of service processes. International journal of service industry management, 3(3), 62-75.

Smith, J. S., Gleim, M. R., Robinson, S. G., Kettinger, W. J., \& Park, S. H. S. (2014). Using an old dog for new tricks: A regulatory focus perspective on consumer acceptance of RFID applications. Journal of Service Research, 17(1), 85-101.

Vaittinen, E., Martinsuo, M., \& Ortt, R. (2018). Business customers' readiness to adopt manufacturer's new services. Journal of Service Theory and Practice, 28(1), 52-78.

Wieske, J., \& Homburg, C. (2008). Understanding the adoption of new brands through salespeople: a multilevel framework. Journal of the Academy of Marketing Science, 36(2), 278-291.

Witell, L., \& Löfgren, M. (2013). From service for free to service for fee: business model innovation in manufacturing firms. Journal of Service Management, 24(5), 520-533.

Yeh, Q. J. (2016). Arguing the Value of Product Quality Signaling in the Presence of Negative Publicity. Journal of Marketing Development and Competitiveness, 10(3), 93. 
Appendix Descriptive statistics of and correlations between variables used in regression

\begin{tabular}{|c|c|c|c|c|c|c|c|c|c|c|c|c|c|}
\hline \multirow{2}{*}{ Variable } & \multirow{3}{*}{ Mean } & \multirow{3}{*}{ Std. } & \multicolumn{11}{|c|}{ Correlations } \\
\hline & & & 1 & 2 & 3 & 4 & 5 & 6 & 7 & 8 & 9 & 10 & 11 \\
\hline $\begin{array}{l}\text { Share of turnover from } \\
\text { the manufacturer's goods }\end{array}$ & & & 1.00 & & & & & & & & & & \\
\hline 2 Number of employees & 9.30 & 23.97 & 0.076 & 1.00 & & & & & & & & & \\
\hline 3 Nationality & & & $.102 *$ & -0.031 & 1.00 & & & & & & & & \\
\hline 4 Age & 45.36 & 9.64 & 0.010 & -0.013 & 0.006 & 1.00 & & & & & & & \\
\hline 5 Gender & & & -0.016 & -0.039 & -0.043 & $-0.124 *$ & 1.00 & & & & & & \\
\hline 6 Registration & & & $0.191 * * *$ & 0.085 & -0.087 & 0.059 & -0.062 & 1.00 & & & & & \\
\hline $\begin{array}{l}\text { Retailer's perceived } \\
\text { usefulness }\end{array}$ & 1.80 & 0.81 & $-0.265 * * *$ & -0.037 & 0.054 & -0.043 & -0.002 & $-0.171 * * *$ & 1.00 & & & & \\
\hline $\begin{array}{l}8 \begin{array}{l}\text { Retailer's perceived ease } \\
\text { of use }\end{array}\end{array}$ & 1.84 & 0.88 & $-0.108 *$ & 0.029 & 0.039 & -0.082 & -0.053 & -0.075 & $0.384 * * *$ & 1.00 & & & \\
\hline $9 \begin{array}{l}\text { Retailer's perceived result } \\
\text { demonstrability }\end{array}$ & 1.57 & 0.79 & $-0.268^{* * *}$ & -0.055 & 0.058 & -0.014 & -0.021 & $-0.110^{*}$ & $0.461 * * *$ & $0.450 * * *$ & 1.00 & & \\
\hline 10 Commitment \& effort & 1.85 & 0.87 & $-0.394^{* * *}$ & -0.033 & 0.071 & -0.075 & -0.053 & $-0.218^{* * *}$ & $0.658^{* * *}$ & $0.364^{* * *}$ & $0.516^{* * *}$ & 1.00 & \\
\hline 11 Manufacturer's support & 1.59 & 0.88 & -0.016 & 0.032 & $0.105^{*}$ & 0.010 & -0.012 & $-0,062$ & $0.313^{* * *}$ & $0.565^{* * *}$ & $0.359^{* * *}$ & $0.203^{* * *}$ & 1.00 \\
\hline 12 Acceptance & & & $-0.291^{* * *}$ & 0.024 & $0.271^{* * *}$ & 0.029 & -0.039 & $-0.248^{* * *}$ & $0.400^{* * *}$ & $0.174^{* * *}$ & $0.368^{* * *}$ & $0.500^{* * *}$ & $0.157^{* *}$ \\
\hline
\end{tabular}


Table 1. Background information about respondents

\begin{tabular}{lc}
\hline Variables & Characteristics \\
\hline Age (avg., range) & 45 years, $19-69$ years \\
Gender (male/female) & $95 \% / 5 \%$ \\
Respondent with service registration & $19 \%$ \\
Respondents from different countries (A/ B/C) & $48 \% / 26 \% / 26 \%$ \\
\hline
\end{tabular}


Table 2 Classification of dependent and control variables

\begin{tabular}{|c|c|c|}
\hline & Variables & Classification \\
\hline Dependent & $\begin{array}{l}\text { Acceptance: (tells about the service } \\
\text { to) }\end{array}$ & $\begin{array}{l}\text { 1) all customers } \\
\text { 2) customers interested in goods that include the } \\
\text { service } \\
\text { 3) customers purchasing goods that include the } \\
\text { service } \\
\text { 4) random customers } \\
\text { 5) none of the customers }\end{array}$ \\
\hline \multirow[t]{6}{*}{ Controls } & Gender & male; female \\
\hline & Age (in years) & $.19-69$ \\
\hline & Nationality & $\mathrm{A} ; \mathrm{B} ; \mathrm{C}$ \\
\hline & Own service registration & no; yes \\
\hline & Percentage of revenues & $0-20 ; 21-40 ; 41-60 ; 61-80 ; 81-100$ \\
\hline & Number of employees & $0-400$ \\
\hline
\end{tabular}


Table 3. Factors, internal consistency and loadings

\begin{tabular}{lc}
\hline Factor (Cronbach's alpha) & Loadings \\
\hline Retailer's perceived usefulness (0.818) & 0.876 \\
The service complements our company's offering well & 0.746 \\
The service improves consumers' image of our company & 0.698 \\
The service eases selling of the products it is related to & 0.538 \\
The trouble from selling and implementing the service pays back for our company & \\
Retailer's perceived ease of use in service implementation (0.776) & 0.891 \\
Overall, the service implementation process is easy & 0.885 \\
The service implementation form is easy to fill out & 0.473 \\
It is easy for me to check the validity of the service from customer's receipt & \\
Commitment \& effort (0.772) & 0.739 \\
The success of the service is important to me & 0.731 \\
I enjoy discussing about the service with customers & 0.720 \\
I invest in telling about the service as much as in telling about our other services & \\
Retailer's perceived result demonstrability (0.806) & 0.974 \\
It is easy to tell customers about the service & 0.717 \\
I have received enough information about the service to market it to customers & 0.631 \\
The customer benefits of the service are evident to me & \\
Manufacturer's support (0.845) & 0.855 \\
Handling service implementation claims goes smoothly with the manufacturer & 0.855 \\
I get help rapidly from the manufacturer if I have something to ask when implementing the & \\
service &
\end{tabular}


Table 4 Results of ordinal regressions: basic model with control variables and full model

\begin{tabular}{|c|c|c|c|c|}
\hline & & Model 1 & Model 2 & Model 3 \\
\hline \multirow[t]{4}{*}{$\begin{array}{l}\text { Threshol } \\
\text { d }\end{array}$} & Acceptance $=1$, High & $-1.790^{*}$ & 1.555 & -1.487 \\
\hline & Acceptance $=2$ & -0.125 & 0.391 & 0.468 \\
\hline & Acceptance $=3$ & .1 .021 & $1.903 *$ & $1.998^{*}$ \\
\hline & Acceptance $=4$, Low & $2.563^{* *}$ & $4.629 * * *$ & $4.870 * * *$ \\
\hline \multirow[t]{24}{*}{ Location } & Share of revenue from manufacturer's goods & $-0.468 * * *$ & $-0.213 *$ & $-0.193^{*}$ \\
\hline & Number of employees & 0.001 & -0.002 & -0.001 \\
\hline & Age & 0.004 & 0.003 & 0.002 \\
\hline & Gender: Male & 0.291 & 0.324 & 0.489 \\
\hline & Gender: Female & & & \\
\hline & Nationality A & $-1.356 * * *$ & $-1.250 * * *$ & $-1.293 * * *$ \\
\hline & Nationality B & $-0.683^{*}$ & $-1.221 * * *$ & $-1.251 * * *$ \\
\hline & Nationality C & & & \\
\hline & Does the retailer use the service: No & $0.905 * * *$ & $0.758 * *$ & $0.739 * *$ \\
\hline & Does the retailer use the service: Yes & & & \\
\hline & Retailer's perceived ease of use & & -0.244 & -0.231 \\
\hline & Retailer's perceived usefulness & & 0.389 & $0.453^{*}$ \\
\hline & Result demonstrability & & 0.479 & 0.419 \\
\hline & Commitment and effort & & $0.864 * * *$ & $0.782 * *$ \\
\hline & Manufacturer's support & & 0.198 & 0.295 \\
\hline & Retailer's usefulness X Manufacturer's support & & & 0.412 \\
\hline & Retailer's ease of Use X Manufacturer's support & & & $-0.304 *$ \\
\hline & $\begin{array}{l}\text { Retailer's result demonstrability X Manufacturer's } \\
\text { support }\end{array}$ & & & 0.291 \\
\hline & Commitment and effort X Manufacturer's support & & & -0.210 \\
\hline & Nagelkerke Pseudo R-Squared & 0.223 & 0.366 & 0.377 \\
\hline & -2 Log Likelihood & 936.60 & .718 .62 & .713 .97 \\
\hline & -2 Log Likelihood Chi-Square & $85.036^{* *}$ & $131.98^{* * *}$ & $136.65 * *$ \\
\hline & Test of parallel lines, Chi-Square & $62.40 * * *$ & $51.33^{*}$ & 50.78 \\
\hline & $* * * \mathrm{p}<0.001, * * \mathrm{p}<0.01, * \mathrm{p}<0.05$ & & & \\
\hline
\end{tabular}




\section{List of figures}

Figure 1. Research model of retailer service acceptance

Figure 2. Illustration of the interaction between manufacturer support and retailer's perceived ease of use in affecting acceptance based on data

Figure 3 The variables and their relation to retailer service acceptance 